\title{
Pemikiran Kontemporer Tafsir al-Qur'an di Indonesia: (Tinjauan Terhadap Buku Pesan-pesan al-Qur'an Mencoba Mengerti Intisari Kitab Suci Karya Djohan Effendi)
}

\author{
Ummi Kalsum Hasibuan \\ UIN Sunan Kalijaga Yogyakarta \\ ukalsumhasibuan@gmail.com
}

\begin{abstract}
This paper examines the discussion of Djohan Effendi's interpretation contained in the book The Qur'anic Messages Trying to Understand the Holy Book. The purpose of this paper is to reveal the portrait of Djohan Effendi's intellectual life, to find out, study and analyze about contemporary thinking from Djohan in interpreting the Koran presented in the form of examples and to analyze the interpretation of the interpretation of the Koran message books created by Djohan. The method used is the descriptive-analysis method using historical. From this, it can be concluded that Djoban Effendi is an Islamic intellectual who came from Banjarmasin and is no longer in the hearings of Islamic thinkers, besides that he is also very enthusiastic about the interpretation of the Koran, so that his last monumental work was successful. Furthermore, related to Djohan's contemporary interpretation in interpreting, he originates from bi al-ra'yi and begins to make an initial understanding with the capital of knowledge and experience in his path, as well as compile the keyword rabbit with God of the pelantan. Then Djohan also does not include the verses of the Koran in it, only the writing of calligraphy is in it. While Djohan's contemporary interpretation expressed in this book he uses more languages and is beautiful for readers This paper will try to discuss or discuss more about the publication of the book Messages of the Koran Trying to Understand the Holy Book written by Djohan Effendi.
\end{abstract}

Keywords: Al-Qur'an, Djohan Effendi, Bi al-Ra'yi

Abstrak: Tulisan ini mengkaji tentang pemikiran tafsir Djohan Effendi yang terdapat dalam buku Pesan-Pesan al-Qu'ran Mencoba Mengerti Intisari Kitab Suci. Tujuan tulisan ini untuk menyingkap potret kehidupan intelektual Djohan Effendi, untuk mengetahui, mengkaji dan menganalisa tentang pemikiran kontemporer dari Djohan dalam melakukan penafsiran al-Qur'an yang dikemukakan dalam bentuk contoh dan untuk menganalisa karakteristik penafsiran dari buku pesan-pesan alQur'an yang dikarang oleh Djohan. Adapun metode yang dipakai adalah metode deskriptif-analisis dengan memakai pendekatan historis. Dari hal tersebut, dapat disimpulkan bahwa Djohan Effendi merupakan intelektual Islam yang berasal dari Banjarmasin dan sudah tidak asing lagi di dengar dari kalangan pemikir Islam, selain itu ia juga sangat antusias terhadap penafsiran al-Qur'an, sehingga lahirlah karya terakhirnya yang monumental tersebut. Selanjutnya terkait pemikiran kontemporer tafsir Djohan dalam melakukan sebuah penafsiran ia bersumber kepada bi al-ra'yi dan berupaya membuat sebuah pemahaman pribadinya dengan modal ilmu pengetahuan dan pengalaman yang dilaluinya, sebagaimana ketika menafsirkan kata 
rabb dengan Tuhan pelantan. Kemudian Djohan juga tidak mencantumkan ayat-ayat al-Qur'an di dalamnya, hanya tulisan kaligrafi saja yang terdapat di dalamnya. Bahkan penafsiran kontemporer Djohan yang teruang dalam bukunya tersebut ia lebih menggunakan bahasa-bahasa sastra maupun indah bagi para pembaca. Tulisan ini akan mencoba untuk mendiskusikan atau meninjau lebih dalam lagi seputar terbitnya buku Pesan-pesan al-Qur'an Mencoba Mengerti Intisari Kitab Suci karangan dari Djohan Effendi.

\section{Kata kunci: Al-Qur'an, Djohan Effendi, Bi al-Ra'yi. PENDAHULUAN}

Allah SWT menurunkan al-Qur'an kepada Nabi Muhammad SAW untuk memberikan petunjuk kepada manusia. Al-Qur'an sebagai mukjizat Nabi Muhammad SAW, terbukti menampakkan sisi kemukjizatanya yang luar biasa, bukan hanya pada eksistensinya yang tidak pernah rapuh, tetapi juga pada ajarannya, yang telah terbukti sesuai dengan perkembangan zaman. Sehingga al-Qur'an menjadi referensi bagi umat di dunia dalam mengarungi kehidupan dunia. al-Qur'an tidak hanya bicara tentang moralitas dan spritualitas, tetapi juga berbicara tentang ilmu pengetahuan yang berkaitan dengan kehidupan umat manusia (Anwar, 2000: 140).

Tafsir merupakan suatu ilmu untuk memahami tentang al-Qur'an dari segala aspek penjelasan maknanya, pengistinbatan (pengambilan), hukum-hukum, dan hikmah-hikmahnya (Al-Suyuthi, 1978: 222-223). Dalam pandangan Islam secara umum, dapat dikatakan bahwa kajian terhadap tafsir merupakan salah satu kajian yang paling mulia dan baik. Hal ini dapat di pahami dari perintah Allah SWT untuk merenungkan dan memikirkan kandungan makna-makna al-Qur'an sebagai petunjuk keselamatan dan kebahagiaan baik di dunia maupun di akhirat.

Seiring dengan berkembangnya zaman yang bergejolak maupun semakin era kekinian, maka dalam melakukan penafsiran terhadap al-Qur'an pun selalu mengalami pergeseran maupun perubahan yang cukup signifikan dalam memahami isi dan ajaran yang terkandung di dalamnya, sehingga pemikiran terhadap suatu penafsiran pun selalu berkembang dari masa ke masa. Tidak hanya terjadi dikalangan umat Islam, melainkan dikalangan umat beragama lainnya.

Pada kehidupan era kekinian ini muncul berbagai upaya dalam memahami al-Qur'an dan mengaplikasikannya dalam kehidupan sehari-hari. Ada yang memahami al-Qur'an itu secara tekstual sebagaimana dipahami dari awal 
terbentuknya Al-Qur'an. Namun ada juga yang memahami al-Qur'an itu dengan menyesuaikan pemahamannya pada konteks perubahan zaman yang mana bisa dilihat dari konteks sosial budaya, ilmu pengetahuan dan peradaban manusia, mulai dari sejak turunnya al-Qur'an hingga sekarang (Syamsuddin, 2002: ix). Terjadinya perubahan terhadap penafsiran tersebut disebabkan dengan munculnya berbagai macam perkembangan pemikiran karya tafsir dengan beragam metode dan corak penafsirannya.

Salah satu tokoh tafsir yang akan dikaji pada era saat ini adalah Djohan Effendi dalam bukunya Pesan-pesan al-Qur'an; mencoba mengerti intisari kitab suci. Di dalam bukunya ia hendak mencoba menjelaskan bahwa ini merupakan pemahaman secara pribadi dan bacaan terhadap al-Qur'an dengan menggunakan modal ilmu pengetahuan maupun pengalaman yang dimilikinya, namun hal tersebut sangat terbatas sebab belum tentu semuanya itu benar-benar tepat dan tidak akan pernah sempurna maupun selesai dalam mengkomunikasikan secara tepat pemahaman kita melalui bahasa dan menyampaikan kepada orang lain (Effendi, 2012: 17).

Walaupun menurut keyakinan bahwa al-Qur'an itu bersifat qath'i, akan tetapi penafsiran dan pemahaman bersifat z̧hanni sehingga hal ini sangat bersifat relatif. Maka tidak seharusnya kita menganggap kalau pemahaman kita itu pasti benar dan pemahaman orang lain pasti salah. Ini bukan omong kosong, melainkan benar-benar bisa di akui kekurangan dan kelemahan sebagai manusia. Hal ini dapat dilihat ketika terdapat perbedaan pemahaman ataupun penafsiran terhadap ayat-ayat al-Qur'an tersebut.

Buku PPQ karangan Djohan Effendi ini ditulis dalam bentuk bahasa Indonesia, karena dalam buku ini menjelaskan tentang upaya untuk lebih mudah dalam memahami pesan-pesan yang terkandung dalam al-Qur'an hanya dengan modal ilmu pengetahuan dan pengalaman yang dimilikinya. Maka dalam tulisan ini akan membahas tentang pemikiran Djohan Effendi.

Sehingga dalam tulisan ini dimaksudkan untuk melakukan sebuah analisis pada salah satu karangan tafsir Indonesia kontemporer yang di tulis oleh Djohan Effendi dalam buku Pesan-pesan Al-Qur'an Mencoba Mengerti Intisari Kitab Suci, 
selain ini Djohan juga memiliki hasil penelitian atau karya lainnya, yaitu: Agama dan Masa Depan, Muhammad: Nabi dan Negarawan, Dialog Antar Agama: Bisakah Melahirkan Teologi Kerukunan dalam Prisma No. 5, Keterbatasan, Kebebasan dan Tanggung Jawab Manusia: Sebuah Tinjauan Tentang Masalah Takdir dari Perspektif Teologi Islam, Tasawuf al-Qur'an tentang Perkembangan Jiwa Manusia, Progressive Traditionalists: the emergence of a new discourse in Indonesia's Nabdlatul Ulama during the Addurrabman Wabid era, Pembaharuan Tanpa Membongkar Tradisi (Wacana keagamaan di Kalangan Generasi Muda NU Mada Kepemimpinan Gus Dur) dan lainlain. Selanjutnya metode yang digunakan dalam menganalisis karya tafsir dari Djohan Effendi, peneliti menggunakan metode deskriptif-analisis. Metode deskriptif-analisis adalah pemaparan secara apa adanya terhadap apa yang dimaksud oleh suatu teks. Pemaparan tersebut dapat dilakukan dengan mengutip secara langsung maupun secara tidak langsung dengan memparafrasekannya sesuai bahasa peneliti.

\section{HASIL DAN PEMBAHASAN}

\section{Selayang Pandang Kehidupan Djohan Effendi}

Nama aslinya adalah Dr. Djohan Effendi dilahirkan pada 01 Oktober 1939 di Banjarmasin. Selain itu, Greg Barton berpendapat dan mengatakan bahwa Djohan lahir di Kandangan Kalimantan Selatan. Merupakan anak dari pasangan H. Mulkani dan $\mathrm{Hj}$. Siti Hadijah. Semasa kecilnya ia lebih sering diasuh oleh neneknya, Hj. Siti Zahrah. Dalam menempuh pendidikannya Djohan memulai belajarnya dengan masuk ke sekolah rakyat selama enam tahun, setelah itu melanjutkannya pada sekolah Arab tiga tahun dan di Banjarmasin pada PGAN selama tiga tahun (Rifat Husnul Ma’afi, Alvin Qodri Lazuardy, 2019: 89).

Kemudian menurut Greg Barton (1999: 175), mengakui atas kepintaran Djohan dalam disertasinya di Monash University Australia yang mana Barton menyamakannya dengan Nurcholis Madjid, Abdurrahman Wahid dan Ahmad Wahib sebagai sesama pemikir neo-modernis Islam. Djohan merupakan sosok orang yang terbuka dan semasa kecilnya ia telah rajin membaca buku biografi tokoh dunia. 
Pada tahun 1957-1960 Djohan melanjutkan pendidikannya ke PHIN Yogyakarta dan menyelesaikannya selama tiga tahun. Ketika ia belajar di PHIN Djohan juga mempelajari tentang filsfat yang paling utama sekali polemik antara alGhazali dan Ibnu Rusyd, beliau pun gemar mempelajari isu-isu teologis dan filosofis yang controversial, seperti tentang keabadian alam, kebebasan manusia dan takdir (Wardani, 2017: 95). Setelah Djohan selesai dalam menempuh pendidikannya di PHIN ia langsung bekerja di pegawai negeri dan kantor pengadilan agama di Amuntai, Hulu Sungai Utara. Kemudian Djohan pergi kembali ke Yogyakarta untuk melanjutkan pendidikannya di IAIN Sunan Kalijaga Yogyakarta tahun 1960 pada jurusan Tafsir Hadis fakultas Syari'ah (Effendi, 2012: 5).

Selain melanjutkan pendidikannya di IAIN Sunan Kalijaga, disinilah Djohan mendapatkan pendidikan formalnya yang terkait dengan tafsir Al-Qur'an sekaligus memulai kembali kajian intelektualnya dengan mengikuti sebuah organisasi HMI yang pada awalnya ia kurang tertarik pada organisasi HMI. Karena pada waktu itu HMI pro dengan Masyumi, ini terlihat secara nyata kalau sangat berbeda dengan ia yang begitu pluralis. Dalam organisasi HMI, Djohan bertemu dengan M. Dawam Rahardjo, Ahmad Wahib, Mansur Hamid dan Nurcholis Madjid. Kemudian Dawam Rahardjo meminta usul kepada Mukhti Ali selaku dosen senior IAIN Sunan Kalijaga untu membentuk kelompok kajian terbatas, bernama limited group pada tahun 1967 sehingga Djohan dan Ahmad Wahib akan segera bergabung dalam kelompok tersebut. Kemudian ia menyelesaikan kuliahnya pada tahun 1969 (Kusuma, 2017: 459).

Kemudian ia meraih gelar sebagai ahli peneliti utama Departemen Agama yang serata dengan profesor atau guru besar dalam perguruan tinggi tahun 1993 (Gaus AF, 2009: 128). Tahun 2001 Djohan mendapatkan gelar doktornya di Australian National University dan Alhamdulillah Djohan Effendi di beri amanah untuk menjadi staf ahli Mensegneg RI, juga ahli peneliti utama di Litbang Departemen Agama RI tahun 1998-2000. Setelah itu Djohan diberi kepercayaan oleh Abdurrahman Wahid untuk menjabat sebagai sekretaris Negara RI mulai dari tahun 2000-2001. Tulisan Djohan pun di muat dari berbagai media massa dan jurnal ilmiah (Hanief Monady, 6). 
Djohan sangat berperan penting dan serius terkait dengan persoalan penafsiran terhadap Al-Qur'an, hal demikian bukan disebabkan ia kuliah pada jurusan Tafsir Hadis di IAIN Sunan Kalijaga, melainkan karena Djohan seorang aktivis yang berperan penting sekaligus terlibat dalam diskusi-diskusi intensif dan juga aktif seputar isu-isu keislaman yang di dalamnya pun mencakup tafsir AlQur'an. Sebagai salah satu pemikir intelektual Islam yang sangat menguasai akan hal tersebut, ketika dalam mendalami Islam Djohan tidak hanya sebagai sebuah teori tetapi juga praktik. Pada usianya lebih dari 70 tahun, ia mengurangi aktivitasnya dan lebih kepada menghabiskan waktunya bersama keluarganya di Australia, dan lebih mengambil dan mendalami makna-makna Al-Qur'an sehingga lahirlah buku PPQ. Hal lainnya Djohan juga berencana untuk menerjemahkan al-Qur'an dengan gaya bahasa yang puitis, sebagaimana yang telah dilakukan oleh HB. Jassin.

Bertepatan pada hari Jum'at 17 November 2017 pukul 22.00 Djohan menghembuskan nafas terakhirnya di Nursing Home Mc Kellar Centre Geelong, Australia ketika itu ia berusia 78 tahun. Kemudian jenazahnya disemayamkan pada hari Senin 20 November 2017 di Werribe cemetery, Melbourne, Victoria merupakan suatu pemukiman yang berjarak sekitar 32 kilometer dari pusat kota Melborne Victoria. (Adristy, 2019: http://www.tempo.com).

\section{Karya-karya Djohan Effendi}

Adapun dalam tulisan Wardani (2017: 97) terdapat beberapa hasil karyakarya yang telah ditulis oleh Djohan Effendi adalah sebagai berikut: 1) Agama dan Masa Depan, 2) Agama dan Pembangunan, 3) Muhammad: Nabi dan Negarawan, 4) Dialog Antar Agama: Bisakah Melahirkan Teologi Kerukunan dalam Prisma No. 5 (1978), 5) Pergolakan Pemikiran Islam, Catatan Harian Ahmad Wahib (1981), 6) Sumbangan Islam kepada Peradaban (1981), 7) Keterbatasan, Kebebasan dan Tanggung Jawab Manusia: Sebuah Tinjauan Tentang Masalah Takdir dari Perspektif Teologi Islam (1984), 8) Tasawuf al-Qur'an tentang Perkembangan Jiwa Manusia dalam Jurnal Ilmu dan Kebudayaan Ulumul Qur'an (1991), 8) Manusia yang tidak menjadi Budak Benda dalam jurnal ilmu dan Kebudayaan Ulumul Qur'an, No. 3 Vol. III, 9) Iqbal: Pemikiran Islam Sosial dan Sajak-sajaknya (1993), 10) Progressive Traditionalists: the emergence of a new discourse in 

Intisari Kitab Suci Karya Djohan Effendi)

Indonesia's Nabdlatul Ulama during the Addurrabman Wabid era, (2000), 11) Sufisme dan Masa Depan Agama (1993), 12) Perkembangan Demokrasi di Indonesia: Sumbangan Agama-agama, 13) Pluralisme dan Demokrasi (1995), 14) Jaminan Konstitusional bagi Kebebasan Beragama di Indonesia,dalam Komaruddin Hidayat dan Ahmad Gaus AF (eds), Passing Over,Melintasi Batas Agama, (1998), 15) Pembaharuan Tanpa Membongkar Tradisi (Wacana keagamaan di Kalangan Generasi Muda NU Mada Kepemimpinan Gus Dur), (2010), 16) Pesanpesan al-Qur'an: Mencoba Mengerti Intisari Kitab Suci merupakan karya terakhir yang di tulis dan dimiliki oleh Djohan Effendi serta ini termasuk karya nya yang terpenting (Wardani, 2017).

\section{Mengenal Secara Umum tentang Buku Pesan-pesan al-Qur'an}

Buku Pesan-pesan al-Qur'an merupakan hasil tulisan dari Djohan Effendi yang diterbitkan di Jakarta, penerbit Serambi, tahun 2012, berjumlah 544 halaman dalam bentuk satu jilid. Al-Qur'an terdiri atas 114 surah yang seluruhnya tersusun secara sistematis dalam tertib mushaf. Maka Djohan dalam menyusun bukunya ini sesuai tartib mushaf dengan cara menguraikan pemahamannya terhadap seluruh ke 114 surah al-Qur'an secara sistematis dan membaginya menjadi tiga bagian, yaitu pembukaan berfungsi sebagai prolog, batang tubuh yang terdiri atas 110 surah dan dibagi lagi menjadi sebelas kelompok yang dimulai dari surah al-Baqarah sampai kepada surah al-Masad dan bagian yang terakhir penutup sebagai epilog, terdiri atas tiga surah, yaitu surah al-Ikhlash, al-Falaq dan al-Nas. Tetapi sangat disayangkan lagi bahwa dalam buku PPQ ini tidak memuat dan menuliskan ayat-ayat al-Qur'an di dalamnya, namun ia hanya menuliskan kaligrafi yang berfungsi sebagai penghias semata (Effendi, 2012: 32).

Kemudian dalam bukunya, ia selalu memuat puisi yang puitis pada setiap akhir pembahasan tema surah. Pembahasannya di awali dengan menafsirkan tentang bismillah lalu melanjutkan pembahasannya dari surah al-Fatihah sampai surah al-Nas dan pada bagian akhir bukunya Djohan menambahkan dua lampiran, lampiran pertama memuat lima tulisan dan lampiran kedua di dalamnya termuat tentang terjemahan puitis surah al-Fatihah dan Juz 'Amma. 


\section{Latar Belakang Penulisan Pesan-pesan al-Qur'an}

Pada mulanya karya Djohan Effendi ini bukanlah bermaksud untuk tujuan akademis saja, melainkan dalam rangka mengambil suatu pesan-pesan yang ada di dalam al-Qur'an. Bukunya ini merupakan sebuah tulisan berdasarkan pemahaman dan pengalaman pribadinya terhadap bacaannya mengenai al-Qur'an dengan bermodal ilmu pengetahuan dan pengalaman yang terbatas sehingga tidak akan pernah tercapai pada tahap penuh. (Effendi, 2012: 17). Maka karangan nya ini di tulis dengan sengaja oleh Djohan Efendi untuk kontribusinya yang terakhir seumpanya suatu saat ia telah di panggil oleh Allah SWT. Namun dirinya tidak memberikan nama buku ini sebagai buku tafsir, tapi merupakan sebuah upaya dalam memahami pesan-pesan dalam al-Qur'an.

Selanjutnya Djohan berbicara sebagai khulasah bahwa mungkin al-Qur'an bukan sebuah dokumen ilmiah; fenomena alam yang di ungkapkannya juga bukan sebagai uraian saintifik dan kisah terkait dengan nabi-nabi serta bukan pula deskripsi historis, apalagi suatu manifesto ideologis. Al-Qur'an merupakan kitab petunjuk dalam rangka untuk berbuat, bekerja, berkarya dan berjasa. Selain itu, Al-Qur'an juga sebagai sumber hidayah.

\section{Sumber, Metode Dan Corak Djohan Efendi dalam Penafsiran al-Qur'an}

\section{Sumber Penafsiran}

Penafsiran Djohan Efendi dalam melakukan sebuah penafsiran pada buku pesan-pesan al-Qur'an pertama sekali bersumber kepada al-Qur'an itu sendiri. Kemudian juga menggunakan sumber rujukan kitab-kitab tafsir yang mudah, simpel baik berbahasa Arab maupun berbahasa Indonesia. Namun tidak begitu banyak kitab tafsir berbahasa Arab yang menjadi rujukan oleh Djohan, jumlahnya sekitar delapan kitab. Djohan lebih banyak mengambil sumber dari buku-buku tafsir, terjemah al-Qur'an dan ulumul Quran berbahasa Inggris.

Sumber tafsir yang digunakan oleh Djohan adalah lebih kepada tafsir bi alra'yi. Selanjutnya ia juga banyak mengenang, mengemban dan terpengaruh oleh guru-gurunya ketika memahami kandungan Al-Qur'an adalah K.H. Dalhar, Prof. Muchtar Jahja, K.H. Ahmad Basyir, Ustd Muchtar Luthfi al-Anshary, Prof. Hasbi Ash-Shiddqie dan Muhammad Irshad. Oleh karena itu dalam penafsiran al-Qur'an 
dapat dilihat bahwa Djohan menggabungkan antara aqli dan naqli serta juga dengan melakukan penafsiran lebih pada sastra dengan menggunakan bahasa yang puitis seperti halnya dengan H.B. Jassin (Effendi, 2012: 25-26).

Dalam melakukan sebuah penafsiran, ia juga sering merujuk kepada kitabkitab tafsir, di antaranya adalah; Tafsir Juz 'Amma karya Muhammad Abduh, Tafsir alQur'an al-Azim karya Syeikh Mahmud Syaltut, Taysir al-Karim ar-Rahman fi Tafsir Kalam al-Manan karya Abdurrahman ibn Nashir As-Sa'di, al-Mufradat fi Gharib alQur'an karya ar-Ragib al-Asfihani, As-Syakhsiyat al-Insaniyat Dirasah Qur'aniyyah karya Abdurrahman Bintu Syati', Commentary on Holy Qur'an karya M. Ghulam Ahmad, Encylopedia of the Holy Qur'an karya N.K. Sigh dan AR. Agwam, Interpretation of the meaning of the Noble Qur'an: a summarized version of at-Tabari, al-Qurtubi and Ibn Kathir with comments from Sabih Bukhari karya Muhammad Muhsin Khan dan Muhammad Taqiuddin al-Hilali (Kusuma 2017: 469).

\section{Metode Dan Corak Penafsiran}

Metode adalah suatu cara yang teratur dan terpikirkan secara baik-baik untuk mencapai kepada suatu pemahaman yang benar tentang apa yang dimaksudkan oleh Allah SWT di dalam ayat-ayat al-Qur'an yang di turunkan-Nya kepada nabi Muhammad SAW ataupun cara-cara menafsirkan al-Qur'an. Sedangkan metodologi adalah ilmu tentang metode menafsirkan al-Qur'an. Dalam hal ini terdapat beberapa metode penafsiran al-Qur'an yang masih umum digunakan oleh para ulama tafsir. Sebagaimana 'Abd al-Hayy al-Farmawi menyebutkan bahwa terdapat empat macam metode penafsiran al-Qur'an, yaitu; metode tafsir tablili, metode tafsir Ijmali, metode tafsir maudhu'i, metode tafsir Muqaran (Al-Farmawi, 1994: 7).

Dalam melakukan sebuah penafsiran pada buku Pesan-pesan al-Qur'an karangan Djohan Effendi, penulis menyimpulkan bahwa ia menggunakan metode tafsir ijmali dan maudbu'i. Hal demikian disebabkan tidak seluruh ayat yang ia tafsirkan, tetapi hanya pada ayat tertentu saja yang ditafsirkannya dan sebatas mengambil maksud dari pokok-pokok kajiannya serta ia juga tidak melakukan penafsiran ayat perayat, kata perkata, namun lebih kepada persurat secara menyeluruh saja dan membagi pembahasan di dalamnya pada beberapa tema. 
Setelah itu, pada kumpulan ayat tersebut di beri judul temanya. Sebagai contoh, penafsirannya pada surah al-Baqarah, ia tidak mencantumkan dan tidak menafsirkan ayat yang berkaitan dengan qishash, namun ia hanya menafsirkan ayat-ayat yang ia pilih.

Corak adalah suatu arah, warna dan kecenderungan pemikiran atau ide yang mendominasi suatu karya tafsir (Sofyan, 2015: 25). Dapat disimpulkan bahwa corak tafsir adalah ragam, jenis dan kekhasan suatu tafsir, dengan pengertian umum corak tafsir adalah kekhususan suatu tafsir yang merupakan dampak dari kecenderungan seorang mufasir dalam menjelaskan maksud ayat-ayat al-Qur'an. Ataupun yang dimaksud dengan corak tafsir adalah ragam dan nuansa khusus yang mewarnai sebuah penafsiran dan merupakan salah satu bentuk ekspresi intelektual seorang mufasir ketika menjelaskan maksud Al-Qur'an.

Pada corak penafsiran buku pesan-pesan al-Qur'an oleh Djohan ini lebih kepada corak adabi al-Ijtima'iy (sosial-masyarakat) dan corak falsafi. Karena pada tema-tema yang di kaji oleh Djohan tentang sosial kemasyarakatan begitu kuat dan juga banyak yang memperbincangkan tentang hal tersebut, seperti: pada QS. AlBaqarah: tema tentang kecaman terhadap eksklusivisme dan membangun umat berkualitas; QS. An-Nisa: bertema terkait hak-hak perempuan, jangan abaikan nasib keluarga, konsolidasi umat. Sedangkan penafsiran bercorak falsafi adalah tema tentang ibadah haji: simbol persatuan dan persamaan yangterdapat dalam QS. AlHajj. (Effendi, 2012: 57, 76 dan 163).

\section{Karakteristik Penafsiran}

Pembahasan mengenai karakteristik penafsiran yang dilakukan Djohan Efendi pada kenyataannya dapat dipengaruhi oleh latar belakang keilmuan dan proses kehidupan yang dijalaninya. Karakteristik Penafsiran Djohan Efendi dalam buku Pesan-pesan al-Qur'an Mencoba Mengerti Intisari Kitab Suci adalah sebagai berikut: 1) Al-Qur'an dijadikan sebagai kitab pedoman dan petunjuk, 2) Menggunakan metode ijmali dan maudhu'I, 3) Banyak menuangkan hasil ide gagasannya, 4) Penafsirannya lebih pada seluruh surah Al-Qur'an dengan menggunakan hasil pemahamannya saja ,5) Selalu memberi prolog atau pengantar di awal pembahasan, 6) Mencantumkan puisi setiap pada akhir pembahasan mengenai 
masing-masing surah tersebut, 7) Tidak memuat ayat-ayat Al-Qur'an di dalamnya, 8) Penafsiran yang dilakukan lebih bersifat universal dan intisari (esensi). Tidak mempersulit dalam hal penafsiran, tetapi langsung intens (substansial) dengan memakai bahasa yang puitis ketika memberi inti dari sebuah pesan pada surah maupun ayat Al-Qur'an.

\section{Contoh Pemikiran Tafsir Djohan Effendi dalam Buku Pesan-pesan Al- Qur'an Mencoba Mengerti Intisari Kitab Suci}

Persoalan penafsiran terhadap al-Qur'an Djohan sangat sensitif mendengarnya, sehingga ia memberi perhatian yang sangat serius maupun mendalam, bukan disebabkan Djohan kuliah pada jurusan Tafsir Hadis Fakultas Syari'ah IAIN Sunan Kalijaga Yogyakarta, melainkan karena Djohan merupakan seorang aktivis dan terlibat dalam diskusi-diskusi yang serius ataupun intensif, baik halnya terkait dengan diskusi dalam ruang lingkup isu-isu keislaman seperti tentang tafsir al-Qur'an, ia berdiskusi bersama teman-temannya, yakni M. Dawam Rahardjo.

Djohan pun juga pernah melakukan suatu diskusi dari kalangan muda yang selalu memberi perhatian khusus terhadap kajian-kajian al-Qur'an, seperti Taufik Adnan dan Syamsu Rizal Panggabean. Hal ini terbukti dari kedua tokoh muda tersebut, yang mana Djohan melakukan diskusi terlebih dahulu sebelum karya mereka itu diterbitkan. Karyanya itu tentang Tafsir Kontekstual Al-Qur'an (Adnan Amal dan Rizal Panggabean1989: 9).

Hal ini dapat dilihat pada sebuah pengantar yang terdapat di dalam bukunya ketika menerjemahkan ungkapan rabb. Pada umumnya para penerjemah memahaminya dengan kata Tuhan, dalam bahasa Inggrisnya Lord. Kata rabb ini memang tidak mungkin di terjemahkan dalam bentuk satu kata yang tepat, sebab ungkapan di dalamnya memuat makna yang luas ataupun mendalam. Maknanya itu mengandung pemilik, pengatur, pencipta, penyedia rezeki, pendidik, penguasa, penjaminan keamanan, perencana terdapat dalam Lisanul Arab dan Tajul Arus. Menurut Imam Raghib al-Asfihani bukunya al-Mufradat fi Gharib al-Qura'n bahwa maksud rabb adalah “insya'u syai'an halal fa halan ila hadittamam” yaitu menumbuhkan sesuatu dari tahap ke tahap sehingga sampai pada tahap yang sempurna. Lain halnya dengan Quraish Shihab yang menerjemahkannya dengan Tuhan Pemelihara. 
Sedangkan Djohan menerjemahkan ungkapan rabb itu dengan menggunakan ungkapan Tuhan Pelantan, walaupun maknanya tidak seluas makna rabb akan tetapi sedikit mendekati maknanya. Kata Lantan bermaksud "membimbing, mengasuh, mengamong, menjaga, mengempu dan merawat (Effendi, 2012: 21).

Dalam bukunya ini Djohan hanya berupaya memaparkan pemahamannya dari ke 114 surah Al-Qur'an yang tersusun secara sistematis sesuai dengan mushaf, dengan bermodal pengetahuan dan pengalaman yang ia lakukan selama ini. Adapun salah satu contoh model pemahaman ataupun penafsiran yang dilakukan oleh Djohan adalah tentang surah al-Hujurat, sebelum menjelaskan suatu sub tema dalam surah, Djohan lebih dahulu mengemukakan gambaran secara umum terkait dengan surah al-Hujurat. Selanjutnya membahas tentang sub tema-tema yang terdapat dalam surah al-Hujurat dan dibagi kepada dua sub tema, yaitu: 1. Tata pergaulan bersama, 2. Umat manusia berbeda untuk saling kenal. Dari kedua tema tersebut, bahwa Djohan tidak mencantumkan ayat di dalamnya, maka untuk merujuk ayatnya diperlukan untuk melihat kembali kepada al-Qur'an.

Tema pertama; Tema pertama surah al-Hujurat setelah penulis melakukan rujukan dalam al-Qur'an, yang mana terdapat dalam ayat 6-12. Dan penjelasan tema tersebut adalah tentang kabar burung atau berita desas-desus sering sekali menjadi pangkal kehebohan dan menimbulkan kekisruhan bahkan kerusuhan dalam masyarakat. Karena itu, muslimin diingatkan agar tidak mudah percaya dengan berita dari seseorang yang tidak jelas kebenarannya. Yang sering kali terjadi lebih berupa desas-desus tanpa dasar selain dugaan dan prasangka. Perlu diselidiki agar tidak terjadi fitnah yang hanya berujung pada penyesalan. Kaum muslimin disadarkan bahwa Allah mengajarkan keindahan iman dalam hati mereka, menghiasi diri mereka dengan sikap menolak kekafiran, tindakan melanggar batas, tidak membenci dan bersikap durhaka. Inilah jalan yang lurus yang harus dihayati kaum muslimin sebagai anugrah dari Tuhan. Apabila terjadi pertikaian ataupun cekcok dikalangan umat Islam maka mereka harus segera mencari jalan agar tidak terus bermusuhan, dan apabila salah satu pihak bersikeras ingin meneruskan pertikaian maka mereka harus dihadapi dan disadarkan sehingga mereka mengikuti perintah Tuhan. Damaikan mereka secara adil sehingga tidak adayang merasa dizalimi. Juga ditekankan 
bagaimana bagaimana sebaiknya memelihara persaudaraan umat beriman.dan mereka tidakboleh saling merendahkan, satu kelompok dengan kelompok lain, kalangan perempuan dengan sesama mereka, sebab bisa saja mereka yang direndahkan justru lebih baik daripada pihak yang merendahkan. Kemudian juga dilarang saling menghina dengan memberikan sebutan yang merendahkan seseorang, sehingga haruslah dicegah sikap prasangka yang mengganggu pergaulan bersama, saling mencari kesalahan dengan memata-matai satu sama lain, serta saling mencaci karena perbuatan itu sama halnya dengan memakan bangkai saudara sendiri.

Tema kedua; tema ini terdapat dalam surah al-Hujurat ayat 13-18 membahas tentang umat manusia berbeda untuk saling mengenal. Sehingga ditekankan dengan keragaman umat manusia, bahwa mereka diciptakan berbangsa-bangsa dan bersukusuku dengan tujuan luhur agar mereka saling mengenal dalam semangat kesetaraan sebab akhirnya yang paling mulia di antara mereka adalah siapa yang paling bertakwa kepada Tuhan. Lalu juga diingatkan bahwa keberimanan seseorang tidak cukup sekedar pengakuan akan tetapi harus berupa keyakinan yang ada dalam hati dan berubah dalam perjuangan di jalan Allah dengan harta kekayaan dan diri mereka sendiri. Semua hal itu tidak akan luput dari namanya pengetahuan Allah yang Maha Melihat segala perbuatan manusia (Effendi 2012: 263-264).

Kemudian setelah menjelaskan tentang tema-tema yang terdapat dalam surah al-Hujurat di atas, lalu pada akhir pembahasan tema setiap surah Djohan dalam bukunya mengemukakan sebuah puisi sebagai penutup penafsiran setiap surah, misalnya puisi tentang penutup penafsiran surah al-Hujurat dan surah alMa'un, sebagai berikut:

\section{Manusia}

Manusia dilabirkan sama

Daripertautan cinta

Ibu dan bapak

Terbagi dalam berbagai umat berbagai puak

Berbagai suku berbagai bangsa

Dan benua

Bukan untuk saling bersaing 
Ummi Kalsum Hasibuan, Tinjauan Terhadap Buku Pesan-pesan al-Qur'an Mencoba Mengerti Intisari Kitab Suci Karya Djohan Effendi)

Saling mengungguli

Satu sama lain

Hidup dalam keragaman

Untuk saling berkenalan

Berlomba dalam kebaikan

Untuk. kemaslahatan bersama

Untuk kepentingan sesama

Sama dan setara

Keturunan atau harta

Bukan ukuran keutamaan

Takwa di dalam dada ukuran penentu

Kemuliaan manusia

Tak bisa diraba

Tiada yang tabu

Kecuali Dia

\section{Pendusta Agama}

Pendusta Agama siapa dia?

Apakab si ateis yang tak percaya Tuban

Ataukah penolak agama yang dibawa Nabi

Ataukah si munafik yang pura-pura beriman?

Tidak!!

Dia yang tak peduli derita simiskin yang menderita

Anak-anak yatim yang bidup terlunta-lunta

Walau shalat take ketinggalan

Tapi Cuma gerak dan ucapan

Hampa tak bermakna (Effendi, 2012: 461). 
Contoh lain yang terdapat dalam buku Pesan-pesan Al-Qur'an terkait dengan Surah an-Nisa' yang terdapat lima tema di dalamnya, yaitu: 1) Manusia seasal dan setara; 2) Perang: derita janda dan anak yatim; 3) Hak-hak perempuan; 4) Konsolidasi umat; 5) Jangan abaikan nasib keluarga. Dari kelima tema dalam surah an-Nisa' tersebut, sebelum mencantumkan salah satu temanya, terlebih dahulu memaparkan suatu prolog terkait dengan surah an-Nisa' yaitu:

An-Nisa' adalah surah ke-4 yang diturunkan di Madinah urutan ke-92, setelah surah al-Mumtahanah dan sebelum surah al-Zalzalah. Sesuai dengan namanya, bahwa surah ini banya berbicara masalah perempuan, di antaranya masalah penderitaan yang mereka tanggung dan alami akibat peperangan. Memang dampak dari peperangan yang terkait langsung dengan kehidupan keluarga, dan karena itu yang paling menderita adalah kalangan perempuan, terutama mereka yang menjadi janda karena ditinggal suami yang tewas di medan perang. Lebih-lebih bila mereka menjadi orang tua tunggal yang harus mengasuh dan membesarkan anak-anak yatim karena ditinggal ayah mereka yang telah gugur dalam peperangan. Lalu surah ini banyak menyinggung masalah janda dan anak yatim yang muncul terutama sebagai akibat perang Uhud sehingga mengakibatkan banyak kaum muslim yang gugur. Perang ini terjadi sebelum surah ini diturunkan, karena itu, surah ini juga membicarakan masalah rumah tangga, pernikahan, harta warisan, dan wasiat.

Kemudian surah ini menggambarkan pentingnya kedudukan serta perannya perempuan, tidak saja dalam kehidupan maupun lingkup keluarga saja, tetapi juga pada lingkup masyarakat yang luas. Kualitas generasi muda menjadi pengisi masa depan yang sangat tergantung pada kualitas dan peran pada kaum perempuan. Selain membahas tentang masalah yang dihadapi keluarga dalam arti sempit, surah ini juga mengkaji permasalahan yang muncul dalam kehidupan umat sebagai keluarga besar kaum muslimin di Madinah. Setelah memaparkan prolog, selanjutnya Djohan menjelaskan kelima tema yang telah disebutkan di atas. Dalam hal ini peneliti hanya memaparkan salah satu tema saja dari kelima tema tersebut adalah sebagai berikut:

Tema tentang Hak-hak perempuan; surah ini juga membicarakan masalah waris secara terperinci. Hal ini sangat penting, karena sering kali yang menyebabkan suatu pertikaian dalam keluarga. Ketentuan-ketentuan ini diperlukan, terutama bila 
tidak terdapat kesepakatan di antara ahli waris, sebagai rujukan bersama. Dalam hal ketentuan pembagian warisan, berbeda dengan zaman sebelumnya, hak-hak perempuan dijamin. Perempuan diperlakukan sebagai manusia sepenuhnya dan tidak lagi sebagai benda yang bisa dijadikan barang warisan. Pengakuan akan hak perempuan ini dinyatakan lebih jauh dengan ketentuan yang jelas dalam memperlakukan kaum perempuan agar mereka tidak dilecehkan dan diperlakukan tidak adil. Laki-laki sebagai suami adalah sebagai penopang keluarga, terutama istri dan anak-anaknya, bukan sebagai penguasa yang bertindak mengungkung dan menghambat karier mereka. Istri juga berhak memiliki bisnis dan penghasilan sendiri. Begitu juga halnya dengan martabat dan kehormatan perempuan harus di junjung tinggi dan mereka tidak boleh dituduh berbuat yang tidak senonoh tanpa kesaksian yang tak terbantahkan. Apabila terjadi perselisihan antara suami-istri, maka harus dicarikan penengah yang bisa mendamaikan mereka dan bisa memberikan pendapat secara objektif dan adil dan mencarikan cara penyelesaian dengan baik. Surah ini juga memerinci tentang perempuan-perempuan yang tidak boleh dinikahi oleh seorang laki-laki. Sebuah ketentuan sangat baik karena pernikahan antara lakilaki dan perempuan yang sangat dekat pertalian darah mereka itu tidak baik untuk menikah (Effendi, 2012: 75-76).

Dalam hal ini Djohan tidak memaparkan ayat al-Qur'an yang menjelaskan terkait tema hak-hak perempuan, oleh sebab itu diperlukannya untuk merujuk kepada al-Qur'an kembali, dalam rangka untuk mengetahui ayat yang di rujuk oleh Djohan Effendi. Setelah merujuk pada al-Qur'an, peneliti menemukan bahwa terkait tema hak-hak perempuan terdapat dalam surah an-Nisa' ayat 15, 23, 24 dan 33. Kemudian di akhir penjelasan mengenai tema-tema dalam surah an-Nisa' Djohan memaparkan sebuah puisi, yaitu:

\section{Ratu Dunia}

Malaikat telah bersujud kepadanya

Karena tak mampu menandingi pengetabuannya

Hidupnya penub kecukupan

Ta' kelaparan tak' kehausan, Ta' telanjang tanpa pakaian

Bukan pula tunawisma ta' punya kediaman 
Ummi Kalsum Hasibuan, Tinjauan Terhadap Buku Pesan-pesan al-Qur'an Mencoba Mengerti Intisari Kitab Suci Karya Djohan Effendi)

Ia bidup dalam Taman Surgawi

Gemah ripah loh jinawi

Tapi belum cukup, Adam kesepian

Ta' betah hidup sendiri

Perlu pasangan dan Hawa didatangkan

Hawa hadir bukan sekedar pelengkap

Bukan jelmaan dari tulang iga, Ia mitra setara

Dari asal dan jenis yang sama

Saling mendukung saling menjaga

Tanpa dominasi

Hawa adalah Ibu manusia

Guru pertama guru utama

Bagi anak-anaknya Generasi masa depan

"Kepada siapa kami harus berbakti"

Kata sahabat kepada Nabi

"Tbumu”, jawabnya pasti

Lalu siapa lagi

"Tbumu dan Ibumu

Kemudian baru Bapakmu"

Ibu adalah Ratu Dunia

Surga berada di bawah telapak kakinya.

Dari kedua contoh yang dikemukakan di atas, tampak jelas bahwa ketika Djohan menafsirkan suatu surah berdasarkan pemahaman dirinya sendiri atas bacaannya terhadap al-Qur'an dengan berpegang pada pengetahuan dan pengalaman yang dimilikinya, lalu dalam penafsirannya ia tidak menafsirkan kata perkata, ayat per ayat, akan tetapi ia menafsirkannya dari surah persurah yang terdapat dalam mushaf dan mengambil intisarinya saja. Selain itu, Djohan juga tidak mencantumkan ayat alQur'an di dalamnya. Kemudian yang lebih uniknya lagi Djohan membuat puisi pada setiap penutup surah yang telah dijelaskannya berdasarkan tema. Kemudian terkait 
dengan sumber penafsiran yang dilakukan oleh Djohan adalah bi al-ra'yi, murni dari pemikiran pribadinya.

Buku PPQ karya Djohan Effendi merupakan karangan terakhir miliknya yang sangat monumental dan penting baginya. Dalam buku karangannya ia menulis berdasarkan pemahaman pribadinya terhadap al-Qur'an atau bacaan-bacaannya tentang al-Qur'an.

Dari penjelasan di atas, maka analisis peneliti tentang pemikiran kontemporer tafsir al-Qur'an yang telah dilakukan Djohan seperti penafsiran tentang kata rabb, yang mana ia menafsirkannya sebagai Tuban Pelantan. Dalam hal ini ketika melakukan suatu pemahaman dan penafsiran terhadap al-Qur'an ia lebih kepada menggunakan bahasa-bahasa sastra, ilmiah ataupun gaya bahasa yang puitis, sekaligus ia juga melakukan berdasarkan pemahaman pribadinya dengan modal bacaan dan pengalamannya. Namun yang lebih disayangkan lagi bahwa dalam buku PPQ karangannya itu ia tidak mencantumkan ayatnya, sehingga menjadi sedikit kesulitan bagi pembaca dan untuk merujuk terlebih dahulu kepada al-Qur'an. Namun dalam bukunya tersebut ia merangkup seluruh surah dalam alQur'an.Terkait pemikiran kontemporer dalam karyanya tersebut ialah dengan model gaya bahasa yang puitis, tidak mencantumkan ayat-ayat, ini berbeda dengan kitab tafsir pada umumnya yang mana mencantumkan ayat, lalu kosa-kata ayat, serta penafsiran.

\section{Kelebihan Dan Kekurangan Pesan-pesan Al-Qur'an Mencoba Mengerti Intisari Kitab Suci}

Menurut hemat penulis, buku Pesan-pesan Al-Qur'an Mencoba Mengerti Intisari Kitab Suci ini memiliki beberapa kelebihan, yaitu: Pertama, mampu mengkaji dan meluahkan pemahamannya pada seluruh surah yang terdapat dalam Al-Qur'an secara menyeluruh. Walaupun Djohan tidak sepenuhnya memaparkan atau membahas ayat Al-Qur'an satu persatu. Kedua, mencantumkan puisi pada setiap akhir surah. Ketiga, berhasilnya Djohan memaparkan satu paragraf prolog atau pengantar pada awal pembahasan di setiap masing-masing surah. Keempat, buku ini memberi kemudahan bagi masyarakat dalam memahami isi kandungan al-Qur'an. Karena buku ini merupakan hasil karangan pribadi dengan berbekal pengetahuan 
dan pengalaman saja. Terkait kritik atau komentar mufasir lainnya peneliti belum menemukannya.

Sedangkan kekurangan dari buku Pesan-pesan Al-Qur'an Mencoba Mengerti Intisari Kitab Suci, yaitu: Pertama, tidak mencantumkan ayat-ayat al-Qur'an yang ditafsirkan dan yang menjadi tema intinya. Kedua, tidak mengkaji terkait dengan ayat-ayat hukum atau yang bercorak fiqih.

\section{PENUTUP}

Berdasarkan kajian di atas, dapat disimpulkan bahwa Djohan Effendi merupakan seorang intelektual Islam yang sudah tidak asing lagi di dengar dengan berbagai macam latar belakang (budayawan, aktivis, dan akademisi) berasal dari Banjarmasin lahir pada 01 Oktober 1939. Dalam bukunya ini ia berusaha menafsirkan dan mengambil intisari-intisarinya saja dengan berbekal pada pengetahuan dan pengalamannya. Buku ini murni atas pemikiran dan pemahaman Djohan terhadap al-Qur'an. Kemudian di dalamnya ia juga tidak mencantumkan seluruh ayat-ayat al-Qur'an sebagaimana model penafsir-penafsir terdahulu lainnya. Terkait dengan pemikiran kontemporer yang tertuang dalam bukunya ketika menafsirkan kata rabb dengan Tuban Pelantan. Selanjutnya dalam 114 surah Al-Qur'an Djohan membaginya dalam tiga bagian, terdiri dari prolog, batang tubuh, epilog. Kemudian kontribusi Djohan Efendi dalam pengembangan Ilmu Studi al-Qur'an yang mana penafsirannya itu menggunakan bahasa yang mudah, singkat ketika di pahami para pembacanya, khususnya bagi pembaca pemula. Serta juga lebih kepada bahasa sastra yang indah dan puitis.

\section{DAFTAR REFERENSI}

Abdul Mustaqim, Sahiron Syamsuddin. (2002). Studi Al-Qur'an Kontemporer Wacana Baru Berbagai Metodologi Tafsir, Yogyakarta:Tiara Wacana.

AF, Ahmad Gaus. (2009). Sang Pelintas Batas: Biografi Djohan Effendi, Jakarta: ICRP dan Kompas.

Anwar, Rosihon. (2000). Ilmu Tafsir, Bandung: Pustaka Setia.

Al-Farmawi, Abd al-Hayy. (1994). Metode Tafsir Maudhu'iy, Suatu Pengantar, Terj. Suryan A. Jamrah, judul asli, Al-Bidayah fi al-Tafsir al-Mandh'iz: Dirasah Manhajiah Mawdhu'iyah, Jakarta: Raja Grafindo Persada. 
Al-Suyuthi, Jalaludin Abd al-Rahman. (1978). Al-Itqan fi Ulum al-Qur'an, Beirut: Dar al-Ma'rifah, Jil. II.

Barton, Greg. (1999) Gagasan Islam Liberal di Indonesia: Pemikiran Neo-Modernisme Nurchalis Madjid, Djohan Effendi, Abmad Wahib, dan Abdurrabman Wabid, Jakarta: Paramadina dan Pustaka Antara.

Charisma Adristy. (2019). diakses pada hari Senin Maret 11, 2019. http://www.tempo.com,Mantan_Mansesneg_Era_Gus_Dur_Djohan_Effen di_MeninggalDunia.

Effendi, Djohan. (2012). Pesan-pesan Al-Qur'an Mencoba Mengerti Intisari Kitab Suci, Jakarta: Serambi Ilmu Semesta.

Hamam Faizin dan Arsyad Sobby Kusuma. (2017). Pemikiran Tafsir Djohan Effendi, dalam Jurnal Raden Intan, Vol 11, Nomor 2.

Hanief Monady. Pesan-Pesan Al-Qur'an: Mencoba Mengerti Intisari Kitab Suci Karya: Djoban Effendi (Studi Kitab Tafsir), dalam academia.edu.

Rif at Husnul Ma'afi, Alvin Qodri Lazuardy. (2019). Konsep Pluralisme Agama Menurut Djohan Effendi, dalam Jurnal Yaqzhan: Analisis Filsafat, Agama dan Kemanusiaan, Vol 5, Nomor 2

Sofyan, Muhammad. (2015). Tafsir walMufassirun, (Medan: Perdana Publishing.

Syamsu Panggabean, Taufik Adnan Amal. (1989). Tafsir Kontekstual al-Qur'an: Sebuah Kerangka Konseptual, Bandung: Mizan.

Wardani. (2017). Trend Perkembangan Pemikiran Kontemporer; Metodologi Tafsir Al-Qur'an Di Indonesia, Banjarmasin, tp. 